\title{
KOMPOSISI JENIS TUMBUHAN BAWAH DAN SIFAT TANAH DI LAHAN BEKAS TAMBANG KAPUR DAN SILIKA PT HOLCIM INDONESIA Tbk
}

\author{
Species Composition of Understorey Vegetation and Soil Properties in Ex Mining Land Silica and \\ Lime Closure PT Holcim Indonesia Tbk
}

Cahyo Wibowo $^{1 *}$, Dadan Mulyana ${ }^{1}$, dan Wiwi Wildasari ${ }^{2}$

(Diterima September 2019/Disetujui Juli 2020)

\begin{abstract}
Mining activities were carried out, causing damage on soils, increased rates of erosion, decline in productivity and stability of the land. The revegetation process takes a long time, so it needs to plant cover crop plants. The goal of planting cover crop is to protect the soil from erosion. This research aims to study the composition of understory vegetation, and its potential to function as cover crops on soil which contain lime and silica in PT Holcim Indonesia Tbk. Undergrowth vegetation which was dominant in the ex- mining land of silica and lime were Imperata cylindrica and Eleusine indica soil properties in both locations were categorized as not fertile.
\end{abstract}

Key words: cover crop, diversity of species, mining, soil properties, understorey

\section{PENDAHULUAN}

Kegiatan penambangan yang dilakukan oleh PT Holcim Indonesia Tbk adalah penambangan batu gamping dan silika. Kegiatan Penambangan dilakukan secara terbuka yaitu dengan cara membuka dan mengupas lapisan tanah bagian atas. Menurut Darwo (2003), pengupasan lapisan atas tanah sangat peka terhadap gangguan, karena eksistensi makhluk hidup terletak pada horison $\mathrm{O}, \mathrm{A}$ dan B.

Dampak negatif kegiatan penambangan terbuka menyebabkan kerusakan vegetasi penutup tanah, kerusakan sistem tata air, peningkatan laju erosi, penurunan produktifitas dan stabilitas lahan serta penurunan kesuburan tanah. Oleh karena itu, kegiatan reklamasi lahan bekas tambang yang perlu dilakukan adalah kegiatan revegetasi. Kegiatan revegetasi membutuhkan waktu yang lama sehingga diperlukan penanaman tanaman penutup tanah terlebih dahulu sebelum dilakukan penanaman pohon. Tanaman penutup tanah (cover crop) adalah tanaman yang ditanam untuk melindungi tanah dari ancaman kerusakan yang disebabkan oleh erosi serta memperbaiki sifat kimia dan fisika tanah.

Kendala dalam penggunaan cover crop yang dipakai untuk revegetasi lahan bekas tambang, salah satunya adalah ketersediaan benih cover crop. Menurut Arafat (2015), benih cover crop belum banyak di komersilkan di Indonesia, oleh karena itu benih harus didatangkan dari luar negeri. Penelitian ini bertujuan untuk mengkaji komposisi jenis, dan potensi tumbuhan bawah untuk

\footnotetext{
${ }^{1}$ Dosen Departemen Silvikultur, Fakultas Kehutanan dan Lingkungan Institut Pertanian Bogor

* Penulis korespondensi:

e-mail: cahyo_odum@yahoo.com

2 Mahasiswa Departemen Silvikultur, Fakultas Kehutanan Institut Pertanian Bogor
}

dijadikan sebagai cover crop di lahan bekas tambang batu silika dan kapur PT Holcim Indonesia Tbk.

\section{METODE PENELITIAN}

\section{Waktu dan Tempat Penelitian}

Penelitian ini dilakukan pada bulan November sampai dengan Desember 2015. Pengambilan data dilakukan di lahan bekas tambang batu kapur Narogong dan lahan bekas tambang silika Sukabumi PT Holcim Indonesia Tbk.

\section{Alat dan Bahan}

Alat yang digunakan pada penelitian ini adalah meteran, patok, tally sheet, kayu pemukul ring, ring contoh tanah dengan ukuran diameter $4.8 \mathrm{~cm}$, cangkul, pisau, garpu besar, kantong plastik $1 \mathrm{~kg}$, peralatan herbarium (alkohol 70\%, gunting, kertas label, plastik besar, kertas koran, sasak, oven), alat tulis, kamera dan buku identifikasi tumbuhan bawah. Bahan yang digunakan dalam penelitian ini adalah jenis tumbuhan bawah dan sampel tanah.

\section{Prosedur Penelitian}

\section{Penentuan plot pengamatan}

Plot pengamatan dibuat pada dua lokasi yaitu lahan bekas tambang kapur dan silika. Lima plot pengamatan diletakkan pada masing - masing lokasi penelitian secara purposive sampling yang dianggap representatif. Total plot pengamatan di dual lokasi berjumlah 10 plot. 


\section{Pembuatan plot pengamatan untuk tumbuhan bawah}

Pada masing-masing lokasi penelitian dibuat 5 plot, masing masing berukuran $2 \mathrm{~m}$ x $2 \mathrm{~m}$ yang diletakkan secara purposif untuk peletakan pot pertama, lalu jarak antar plot dibuat $40 \mathrm{~m}$.

\section{Pembuatan herbarium dan identifikasi jenis}

Pembuatan herbarium dilakukan untuk mengidentifikasi jenis tumbuhan bawah yang belum teridentifikasi di lapangan. Tumbuhan bawah yang belum teridentifikasi dibuat herbariumnya dengan cara dikeringkan dalam oven pada suhu $150^{\circ} \mathrm{C}$ selama 24 jam. Kegiatan pembuatan herbarium dan identifikasi jenis tumbuhan bawah dilakukan di Laboratorium Ekologi Fakultas Kehutanan IPB.

\section{Pengambilan sampel tanah}

Pengambilan sampel tanah untuk analisis sifat kimia tanah diambil sampai kedalaman $20 \mathrm{~cm}$ dengan teknik mencangkul. Sampel tanah diambil dari 5 titik plot contoh pada setiap lokasi penelitian, kemudian tanah dikompositkan dan diambil sebanyak $1 \mathrm{~kg}$ untuk dianalisis. Pengambilan sampel tanah untuk analisis sifat fisika tanah dilakukan dengan mengambil sampel tanah utuh menggunakan ring tanah sebanyak 4 ring. Ring tanah ditekan sampai badan ring tertanam di dalam tanah. Ring yang sudah tertanam diambil menggunakan cangkul untuk mengeluarkan ring yang telah berisi sampel tanah, kemudian tanah bagian bawahnya diiris menggunakan pisau untuk meratakan permukaan bagian bawah. Ring yang berisi tanah dilapisi dengan perekat bening supaya terjaga keutuhannya.

\section{Analisis data}

Analisis data yang digunakan untuk mengetahui gambaran tentang komposisi jenis tumbuhan bawah adalah perhitungan analisis vegetasi. Pengolahan data hasil analisis vegetasi meliputi terutama Indeks Nilai Penting.

\section{Indeks nilai penting}

Indeks Nilai Penting (INP) merupakan parameter kuantitatif yang dipakai untuk mengetahui tingkat dominansi spesies-spesies dalam suatu komunitas tumbuhan (Soegianto1994 dalam Indriyanto 2010).

$\mathrm{INP}=\mathrm{KR}+\mathrm{FR}$

\section{HASIL DAN PEMBAHASAN}

\section{Jumlah Jenis Tumbuhan Bawah pada Setiap Lokasi Penelitian}

Jumlah jenis tumbuhan bawah secara umum sangat beragam pada masing-masing lahan bekas tambang di PT Holcim Indonesia Tbk. Berdasarkan Gambar 1 bahwa jumlah jenis tumbuhan bawah yang ditemukan pada lahan bekas tambang kapur yaitu 31 jenis tumbuhan bawah dari 20 famili, sedangkan pada lahan bekas tambang silika ditemukan 22 jenis tumbuhan bawah dari
9 famili. Total jumlah jenis yang ditemukan pada kedua lokasi sebanyak 51 jenis dari 24 famili.

\section{Dominansi jenis tumbuhan bawah pada setiap lokasi penelitian}

Beradsarkan Tabel 1 bahwa jenis tumbuhan bawah yang paling dominan di lahan bekas tambang kapur adalah jenis Ageratum conyzoides dengan INP 10.34\%, Bidens pilosa dengan INP $10.79 \%$, Mimosa pudica dengan INP $14.91 \%$, Cyperus rotundus dengan INP 17.28 dan Eulesine indica dengan INP 38.08.

Berdasrakan Tabel 2 bahwa Jenis tumbuhan yang paling dominan pada lahan bekas tambang silika adalah jenis Panicum paludosum dengan INP 10.41\%, Pennisetum polystachyon dengan INP $12.47 \%$, Mimosa pudica dengan INP $15.01 \%$, Calopogonium muconoides dengan INP $15.93 \%$, Paspalum cartilagineum dengan INP $17.05 \%$, Paspalum conjugatum dengan INP 19.76\% dan Imperata cylindrica dengan INP $32.90 \%$.

\section{Keanekaragaman Jenis Tumbuhan Bawah}

Nilai indeks keanekaragaman, kekayaan, kemerataan dan dominansi jenis tumbuhan bawah pada setiap lokasi penelitian disajikan pada Tabel 1. Keanekaragaman jenis (H') pada masing - masing lokasi penelitian memiliki nilai yang tidak jauh berbeda. Nilai keanekaragaman jenis pada lahan bekas tambang kapur sebesar 2.46 dan pada lahan bekas tambang silika sebesar 2.47. Nilai indeks kemerataan jenis (E) pada lahan bekas tambang silika lebih tinggi diandingkan dengan lahan bekas tambang kapur. Nilai indeks kakayaan jenis $\left(\mathrm{R}_{1}\right)$ pada lahan bekas tambang kapur lebih tinggi (4.05) dibandingkan dengan lahan bekas tambang silika (3.38). Nilai indeks dominansi (C) pada lahan bekas tambang kapur sebesar 0.07 sedangkan pada lahan bekas tambang silika sebesar 0.11. Nilai indeks kesamaan antara lahan bekas tambang kapur dengan lahan bekas tambang silika memiliki nilai yang rendah sebesar $12.46 \%$.

\section{Sifat Fisika Tanah}

Tanah pada lahan bekas tambang silika memiliki tekstur sandy clay loam yang didominasi oleh kandungan pasir yang tinggi yaitu 58\%. Tanah di lahan bekas tambang kapur memiliki tekstur sandy clay loam yang

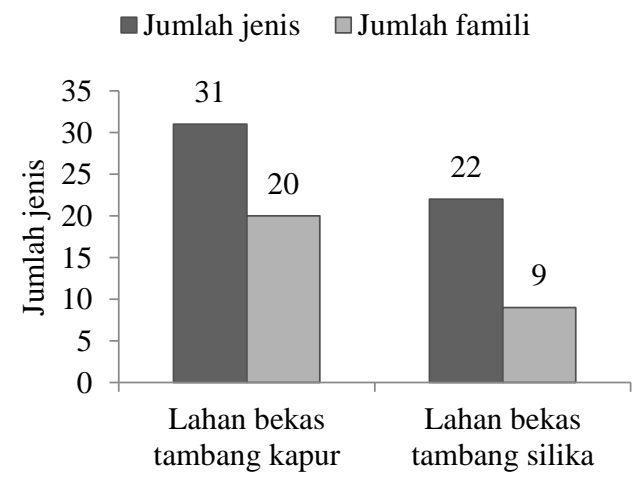

Gambar 1 Jumlah jenis tumbuhan bawah padasetiap lokasi penelitian 
didominasi oleh kandungan pasir yang tinggi yaitu $46 \%$. Bulk density (BD) pada lahan bekas tambang silika lebih tinggi (1.23 $\left.\mathrm{gr} / \mathrm{cm}^{3}\right)$ dibandingkan dengan lahan bekas tambang kapur $\left(1.07 \mathrm{gr} / \mathrm{cm}^{3}\right)$. Particle density(PD) pada lahan bekas tambang silika lebih tinggi $\left(2.40 \mathrm{gr} / \mathrm{cm}^{3}\right)$ dibandingkan dengan lahan bekas tambang kapur (2.31 $\mathrm{gr} / \mathrm{cm}^{3}$ ). Ruang pori total di lahan bekas tambang silika lebih tinggi ( $\left.54.75 \mathrm{gr} / \mathrm{cm}^{3}\right)$ dibandingkan dengan tanah di lahan bekas tambang kapur $\left(46.75 \mathrm{gr} / \mathrm{cm}^{3}\right)$. Nilai KAL pada lahan bekas tambang silika lebih tinggi $(25.88 \%$ vol) dibandingkan dengan lahan bekas tambang kapur (25.33\% vol). Permeabilitas pada lahan bekas tambang kapur lebih tinggi $(6.96 \mathrm{~cm} / \mathrm{jam})$ dibandingkan dengan lahan bekas tambang silika $(2.99 \mathrm{~cm} / \mathrm{jam})$.

\section{Analisis Sifat Kimia Tanah}

Nilai $\mathrm{pH} \mathrm{H}_{2} \mathrm{O}$ dan $\mathrm{KCl}$ tanah pada lahan bekas tambang kapur termasuk kedalam kriteria masam sedangkan pada lahan bekas tambang silika termasuk kedalam kriteria agak alkalis.Kandungan C organik lahan bekas tambang kapur lebih tinggi $(0.98 \%)$ dibandingkan dengan lahan bekas tambang silika $(0.75 \%)$, sementara untuk nilai $\mathrm{N}$ total lahan bekas tambang silika lebih tinggi (0.08\%) dibandingkan dengan lahan bekas tambang kapur (0.07). Nisbah $\mathrm{C} / \mathrm{N}$ pada lahan bekas tambang kapur lebih tinggi (14\%) dibandingkan dengan lahan bekas tambang silika (9\%). Nilai P tersedia pada lahan bekas tambang kapur sebesar 25 ppm dan lahan bekas tambang silika sebesar $7.8 \mathrm{ppm}$.

Tanah pada masing-masing lokasi penelitian mengandung unsur Magnesium yang tergolong sedang; unsur Nitrogen, Fosfor dan Kalium yang tergolong rendah. kandungan unsur Kalsium pada lahan bekas tambang kapur tergolong sangat tinggi sedangkan pada lahan bekas tambang silika tergolong sangat rendah. Kapasitas tukar kation pada lahan bekas tambang kapur tergolong sedang, sementara untuk lahan bekas tambang silika tergolong rendah. Kandungan KB pada lahan bekas tambang kapur tergolong sangat tinggi, sedangkan pada lahan bekas tambang silika tergolong rendah.

\section{Jumlah Jenis Tumbuhan Bawah}

Jumlah tumbuhan bawah di lahan bekas tambang kapur lebih tinggi dibandingkan dengan lahan bekas tambang silika. Hal ini diduga karena terbukanya lahan tanpa pohon penaung mengakibatkan tumbuhan bawah di lahan bekas tambang kapur tumbuh lebih banyak. Hasil penelitian ini berbanding lurus dengan pernyataan Indriyanto (2008) bahwa tajuk pohon yang rapat menyebabkan matahari tidak dapat menembus lantai hutan, sehingga tidak memungkinkan bagi tumbuhan bawah untuk berkembang di bawah naungan tajuk pohon kecuali jenis tumbuhan yang telah beradaptasi dengan baik untuk tumbuh di bawah naungan. Rendahnya komposisi jenis tumbuhan bawah di lahan bekas tambang silika diduga karena terdapat pohon pinus di lahan tersebut. Senyawa alelopati yang berasal dari pinus diduga memengaruhi komposisi jenis tumbuhan bawah. Menurut Saminga (1988) dalam Kunarso et al. (2012), tanaman pinus menghasilkan senyawa alelopati yang menyebabkan akumulasi nitrogen terhambat sehingga

Tabel 1 Jenis tumbuhan bawah di lahan bekas tambang kapur

\begin{tabular}{|c|c|c|c|c|}
\hline No & Nama Jenis & Famili & INP $(\%)$ & Keterangan*) \\
\hline 1 & Eleusine indica & Poaceae & 38.08 & Invasif \\
\hline 2 & Cyperus rotundus & Cyperaceae & 17.28 & Invasif \\
\hline 3 & Mimosa pudica & Fabaceae & 14.91 & Invasif \\
\hline 4 & Bidens pilosa & Asteraceae & 10.79 & Invasif \\
\hline 5 & Ageratum conyzoides & Asteraceae & 10.34 & Invasif \\
\hline 6 & Spigelia anthelmia & Loganiaceae & 8.46 & Invasif \\
\hline 7 & Centella asiatica & Apiaceae & 8.03 & tidak invasif \\
\hline 8 & Paspalum vaginatum & Poaceae & 7.91 & Invasif \\
\hline 9 & Gendarussa vulgaris & Acanthaceae & 6.34 & tidak invasif \\
\hline 10 & Phyllanthus urinaria & Phyllanthaceae & 6.32 & tidak invasif \\
\hline 11 & Lindernia anagallis & Linderniaceae & 5.79 & tidak invasif \\
\hline 12 & Amaranthus spinosus & Amaranthaceae & 5.79 & Invasif \\
\hline 13 & Imperata cylindrica & Poaceae & 5.62 & Invasif \\
\hline 14 & Fimbristylis aphylla & Cyperaceae & 4.92 & tidak invasif \\
\hline 15 & Isachne globosa & Poaceae & 4.92 & tidak invasif \\
\hline 16 & Digitaria ciliaris & Poaceae & 4.76 & Invasif \\
\hline 17 & Phyllanthus debilis & Phyllanthaceae & 4.24 & tidak invasif \\
\hline 18 & Brachiaria paspaloides & Gramineae & 3.91 & Invasif \\
\hline 19 & Paspalum commersonii & Poaceae & 2.66 & Invasif \\
\hline 20 & Sida rhombifolia & Malvaceae & 2.43 & Invasif \\
\hline 21 & Vigna trilobata & Fabaceae & 2.35 & tidak invasif \\
\hline 22 & Hydrolea zeylanica & Hydrophyllaceae & 2.27 & Invasif \\
\hline 23 & Bergia capensis & Elatinaceae & 2.27 & Invasif \\
\hline 24 & Oxalis barrelieri & Oxalidaceae & 2.27 & Invasif \\
\hline 25 & Aeschynomene indica & Fabaceae & 2.27 & Invasif \\
\hline 26 & Mikania micrantha & Asteraceae & 2.20 & Invasif \\
\hline 27 & Ipomoea triloba & Convolvulaceae & 2.20 & Invasif \\
\hline 28 & Portulaca oleracea & Portulaceae & 2.20 & Invasif \\
\hline 29 & Mimosa invisa & Fabaceae & 2.12 & Invasif \\
\hline 30 & Euphorbia heterophyllaa & Euphorbiaceae & 2.12 & Invasif \\
\hline 31 & Cardiospermum halicacabum & Sapindaceae & 2.12 & tidak invasif \\
\hline
\end{tabular}

*) Keterangan: SEAMEO BIOTROP 2008 
pertumbuhan tanaman akan terhambat pula karena tidak dapat menyerap unsur $\mathrm{N}$ secara optimal.

\section{Dominansi Jenis Tumbuhan}

Indeks Nilai Penting (INP) menunjukkan peranan suatu jenis dalam sebuah komunitas. Jenis yang memiliki nilai INP paling tinggi merupakan jenis yang mendominasi. Sutisna (1981) dalam Gustiani (2015), menyatakan bahwa suatu jenis memiliki peran yang besar dalam komunitas apabila nilai INP jenis tersebut lebih dari $10 \%$ untuk tingkat tumbuhan bawah. Terdapat dua jenis tumbuhan bawah yang selalu ditemukan pada kedua lokasi penelitian, yaitu Imperata cylindrica dan Eulesine indica yang termasuk kedalam famili Poaceae. Jenis ini berasal dari daerah tropis Amerika, di Indonesia hampir tersebar merata pada semua daerah (Gustiani 2015). Kedua jenis tumbuhan bawah ini diduga memiliki daya adaptasi lingkungan yang tinggi sehingga dapat tumbuh di lahan bekas tambang kapur dan silika.

\section{Keanekaragaman Jenis Tumbuhan Bawah}

Nilai indeks kekayaan jenis $\left(\mathrm{R}_{1}\right)$, keanekaragaman jenis (H') dan kemerataan jenis (E) merupakan gambaran secara kuantitatif mengenai kondisi keanekaragaman suatu komunitas. Penggunaan indeks kekayaan jenis pada penilaian keanekaragaman bertujuan untuk mengetahui jumlah jenis yang ditemukan pada suatu komunitas. Berdasarkan klasifikasi Mangurran (2004) nilai $\mathrm{R}_{1}$ tumbuhan bawah yang terdapat di lahan bekas tambang kapur tergolong sedang, sementara indeks kekayaan lahan bekas tambang silika tergolong rendah. Perbedaan nilai kekayaan jenis pada kedua lokasi penelitian dipengaruhi oleh jumlah jenis yang ditemukan di lokasi penelitian. Berdasarkan klasifikasi Mangurran (2004) nilai H' pada kedua lokasi penelitian menunjukkan keragaman jenis yang tergolong sedang. Hal tersebut dipengaruhi oleh kegiatan penambangan di kedua lokasi sehingga lingkungannya terganggu dan menyebabkan jenis tumbuhan bawah yang ditemukan hanya sedikit. Menurut Mangurran (2004) besaran nilai $\mathrm{E}<0.3$ menunjukkan kemerataan jenis tergolong rendah, $\mathrm{E}=0.3-0.6$ menunjukkan kemerataan jenis tergolong sedang dan $\mathrm{E}>0.6$ menunjukkan kemerataan jenis tergolong tinggi. Berdasarkan klasifikasinya kemerataan jenis pada masing - masing lokasi penelitian tergolong tinggi.

Menurut Istomo dan Kusmana (1997) indeks dominansi adalah suatu ukuran untuk memeriksa tingkat penguasaan suatu jenis dalam komunitas. Nilai indeks dominansi mendekati 1 tergolong tinggi, artinya dominansi terpusat pada satu atau beberapa jenis dan jika nilai indeks dominansi mendekati 0 tergolong rendah, artinya dominansi jenis dipusatkan pada banyak jenis. Berdasarkan hasil perhitungan indeks dominansi pada kedua lokasi penelitian menunjukkan bahwa nilai indeks dominansi tergolong rendah yang artinya jenis tumbuhan bawah pada kedua lokasi penelitian menyebar pada banyak jenis.

Tabel 2 Jenis-jenis tumbuhan bawah di lahan bekas tambang silika

\begin{tabular}{cllcl}
\hline No & & \multicolumn{1}{c}{ Nama Jenis } & INP $(\%)$ & Keterangan ${ }^{*}$ \\
\hline 1 & Imperata cylindrica & Poaceae & 32.90 & Invasif \\
2 & Paspalum conjugatum & Poaceae & 19.76 & Invasif \\
3 & Paspalum cartilagineum & Poaceae & 17.05 & Invasif \\
4 & Calopogonium muconoides & Fabaceae & 15.93 & tidak invasif \\
5 & Mimosa pudica & Fabaceae & 15.01 & Invasif \\
6 & Pennisetum polystachyon & Poaceae & 12.47 & Invasif \\
7 & Panicum paludosum & Poaceae & 10.41 & Invasif \\
8 & Mimosa invisa & Fabaceae & 9.57 & Invasif \\
9 & Echinochloa stagnina & Poaceae & 8.62 & Invasif \\
10 & Ischaemum ciliare & Poaceae & 7.43 & tidak invasif \\
11 & Ishaemum rugosum & Poaceae & 6.63 & tidak invasif \\
12 & Paspalum longifolium & Poaceae & 6.51 & Invasif \\
13 & Calopogonium polytscyon & Fabaceae & 6.24 & tidak invasif \\
14 & Melastoma malabathricum & Melastomataceae & 4.25 & Invasif \\
15 & Ischaemum timorense & Poaceae & 4.25 & tidak invasif \\
16 & Tridax procumbens & Asteraceae & 3.85 & Invasif \\
17 & Lycopidium clavantum & Lycopidium & 3.65 & tidak invasif \\
18 & Clidemia hirta & Melastomataceae & 3.25 & Invasif \\
19 & Ludwigia hyssopifolia & Onagraceae & 3.06 & Invasif \\
20 & Bacopa procumbens & Scrophulariaceae & 3.06 & tidak invasif \\
21 & Oxalis barrelieri & Oxalidaceae & 3.06 & Invasif \\
22 & Crotalaria retusa & Fabaceae & 3.06 & tidak invasif \\
\hline & & &
\end{tabular}

*) Keterangan : SEAMEO BIOTROP 2008 


\section{Indeks Kesamaan Jenis (IS)}

Indeks kesamaan jenis menggambarkan tingkat kesamaan antara beberapa komunitas. Menurut Istomo dan Kusmana (1997) jika nilai IS < 75\% maka dua komunitas yang dibandingkan dianggap berbeda dan jika nilai IS $\geq 75 \%$ maka kedua komunitas yang dibandingkan dianggap sama. Nilai IS yang diperoleh dari hasil perhitungan IS pada kedua tempat menunjukkan bahwa terdapat perbedaan komposisi tumbuhan bawah yang cukup signifikan. Perbedaan struktur ini diduga dipengaruhi oleh faktor lingkungan seperti kondisi tanah, $\mathrm{pH}$ tanah, suhu tanah dan curah hujan.

\section{Analisis Sifat Fisika Tanah}

Tekstur tanah adalah perbandingan relatif antara fraksi pasir, debu dan klei dalam masa tanah. Tekstur tanah menunjukkan kasar halusnya tanah dari fraksi tanah halus (Hardjowigeno 2010). Tanah pada lahan bekas tambang kapur termasuk ke dalam tekstur silty clay yang didominasi oleh kandungan debu. Tanah yang terdapat di lahan bekas tambang silika termasuk ke dalam tekstur sandy clay loam yang didominasi oleh kandungan pasir. Tekstur tanah sangat memengaruhi kemampuan tanah dalam memegang air. Tanah bertekstur liat memiliki kemampuan yang lebih besar dalam memegang air dibandingkan tanah bertekstur pasir hal ini terkait dengan luas permukaan adsorptifnya, semakin halus teksturnya akan semakin besar kapasitas menyimpan airnya (Haridjaja 2013). Tanah bertekstur lempung dianggap sebagai tanah yang mempunyai bahan organik tinggi dan optimal bagi pertumbuhan tanaman, karena kapasitas tanah menahan air dan unsur hara lebih baik dibandingkan tanah berpasir, sedangkan drainase dan aerasenya lebih baik dibanding liat (Mahmud 2014).

Bulk density (BD) adalah petunjuk kepadatan tanah, yaitu menunjukkan perbandingan antara berat tanah kering dengan volume tanah termasuk volume pori - pori tanah. Makin padat suatu tanah, semakin tinggi $\mathrm{BD}$, yang berarti semakin sulit meneruskan air atau ditembus akar tanaman. Menurutt Hardjowigeno (2003) pada umumnya BD tanah mineral berkisar antara 1.1 $1.6 \mathrm{~g} / \mathrm{cm}^{3}$. BD tanah pada masing - masing lokasi penelitian tergolong sedang. Besarnya BD tanah pada masing - masing lahan diduga adanya pemadatan tanah akibat penggunan alat - alat berat pada saat kegiatan penambangan.

Particle density (PD) adalah nisbah antara bobot kering partikel padat tanah terhadap volumenya (Hardjowigeno 2003). Nilai PD partikel merupakan fungsi dari perbandingan antara komponen bahan mineral dan bahan organik. Nilai PD tanah mineral umumnya berkisar antara $2.60 \mathrm{~g} / \mathrm{cm}^{3}-2.70 \mathrm{~g} / \mathrm{cm}^{3}$ (Puja 2008 dalam Ritonga 2015). Nilai PD tanah di lahan bekas tambang silika lebih rendah dibandingkan dengan lahan bekas tambang kapur. Hal ini diakibatkan oleh kandungan bahan organik yang berbeda. Menurut Ritonga (2015) semakin tinggi bahan organik tanah maka semakin kecil nilai PD.

Ruang pori total (RPT) tanah merupakan bagian tanah yang ditempati air dan udara. RPT di dalam tanah sangat erat kaitannya dengan $\mathrm{BD}$, menurut Subandiono et al. (2014) peningkatan BD menyebabkan total RPT menurun. Nilai RPT di lahan bekas tambang silika lebih tinggi dibandingkan dengan tanah di lahan bekas tambang kapur, kondisi ini disebabkan oleh nilai BD yang rendah di lahan bekas tambang silika.

Kadar air lapang (KAL) adalah kadar air tanah pada saat pengukuran di lapangan (Pratiwi 2014). Kadar air di lahan bekas tambang kapur memiliki kadar air lebih tinggi dibandingkan dengan lahan bekas tambang silika. Hal ini menunjukkan kemampuan tanah menyimpan dan memegang air pada lahan bekas tambang kapur termasuk tinggi. Rendahnya kadar air di lahan bekas tambang silika dibandingkan lahan bekas tambang silika menyebabkan kemampuan tanah memegang air lebih rendah. Rendahnya kadar air di lahan bekas tambang silika juga disebabkan oleh kadar bahan organik yang lebih rendah dibandingkan lahan bekas tambang kapur.

Permeabilitas adalah kemampuan tanah untuk meloloskan air pada tanah dalam keadaan jenuh. Permeabilitas umumnya diukur dengan laju aliran air melalui tanah dalam suatu waktu dan umumnya dinyatakan dalam cm/jam (Foth 1988 dalam Pratiwi 2014). Permeabilitas pada lahan bekas tambang kapur dan silika secara berturut - turut tergolong agak cepat dan sedang. Kemampuan tanah menahan air dipengaruhi oleh tekstur tanah. Tanah bertekstur halus akan menahan air lebih banyak dibandingkan dengan tanah bertekstur kasar. Oleh karena itu, tanah bertekstur pasir lebih mudah kekeringan sehingga mengganggu pertumbuhan tanaman.

\section{Analisis Sifat Kimia Tanah}

Hilangnya lapisan tanah atas merupakan indikasi buruknya tingkat kesuburan tanah pada lahan bekas penambangan. Menurut Asir (2013), kendala areal bekas penambangan bahan baku semen yang paling utama ditemukan adalah ketersediaan unsur hara yang esensial seperti Nitrogen, Fosfor, toksisitas mineral kemasaman tanah atau $\mathrm{pH}$ tanah yang tidak normal dapat terjadi rendah atau sebaliknya.

Reaksi tanah menunjukkan sifat kemasaman tanah yang dinyatakan dengan nilai $\mathrm{pH}$ tanah. Nilai $\mathrm{pH}$ tanah sangat penting untuk menentukan mudah tidaknya unsurunsur hara diserap oleh tanaman serta menunjukkan kemungkinan adanya unsur-unsur beracun pada tanah (Hardjowigeno 2010). Nilai $\mathrm{pH} \mathrm{H}_{2} \mathrm{O}$ dan $\mathrm{pH} \mathrm{KCl}$ adalah kandungan air yang dapat terikat pada tanah dan topsoil (Sembiring 2008). Nilai pH tanah pada lahan bekas tambang silika bersifat masam sedangkan nilai $\mathrm{pH}$ tanah pada lahan bekas tambang kapur bersifat agak alkalis. Tanah masam tidak dapat menyerap unsur $\mathrm{P}$ karena diikat oleh unsur Al sedangkan pada tanah alkalis unsur $\mathrm{P}$ juga tidak dapat diserap tanaman karena diikat oleh unsur Ca. Nilai $\mathrm{pH}$ tanah masam dapat dinaikan dengan cara menambahkan kapur ke dalam tanah sedang $\mathrm{pH}$ tanah alkalis dapat diturunkan dengan cara menambahkan belerang (Hardjowigeno 2010).

Kandungan $\mathrm{C}$ organik dan $\mathrm{N}$ total di masing masing lokasi penelitian tergolong sangat rendah, sementara nisbah $\mathrm{C} / \mathrm{N}$ tergolong rendah dan sedang. Menurut Larson dan pierce (1994) dalam Subandiono et al. (2014) bahan organik memegang peranan yang penting terhadap kualitas tanah, penurunan $\mathrm{C}$ organik mengindikasikan penurunan kualitas tanah. Bahan 
organik memengaruhi kemampuan tanah memegang dan menyediakan hara dan air bagi tanaman, mendorong dan mempertahankan pertumbuhan akar, menciptakan habitat yang sesuai untuk biotik dan menahan degradasi.

Unsur hara $\mathrm{P}$ tersedia adalah $\mathrm{P}$ tanah yang dapat larut dalam air dan asam nitrat. Nilai $\mathrm{pH}$ tanah terhadap ketersediaan unsur $\mathrm{P}$ dapat digunakan sebagai salah satu tolak ukur untuk membandingkan hasil uji P. Metode Olsen biasanya digunakan untuk tanah yang memiliki $\mathrm{pH}$ $>5.5$, sedangkan metode Bray biasanya digunakan untuk tanah yang memiliki $\mathrm{pH}<5.5$ (Umaternate et al 2014). Berdasarkan penilaian sifat kimia tanah (Staf PPT 1983), kandungan P tersedia di lahan bekas tambang silika dan kapur berturut-turut tergolong kedalam kriteria rendah dan sangat rendah. Rendahnya nilai P tersedia di lahan bekas tambang silika diduga dipengaruhi oleh rendahnya nilai $\mathrm{pH}$ tanah yang tergolong masam, sedangkan rendahnya nilai $\mathrm{P}$ pada lahan bekas tambang kapur dipengaruhi oleh $\mathrm{pH}$ tanah yang tergolong alkalis. Unsur $\mathrm{P}$ yang rendah dapat mengakibatkan pertumbuhan tanaman terhambat karena pembelahan sel terganggu.

Kapasitas Tukar Kation (KTK) merupakan sifat kimia tanah yang sangat erat hubungannya dengan kesuburan tanah, sebab tanah tidak akan mampu menyerap dan menyediakan unsur hara bagi pertumbuhan tanaman apabila memiliki KTK yang rendah (Hardjowigeno 2003). Hasil analisis sifat kimia tanah pada KTK di lahan bekas tambang silika tergolong rendah sedangkan pada lahan bekas tambang kapur tergolong sedang. Menurut Setiadi (2012) dalam Oktavia (2014), rendahnya nilai KTK akan mengakibatkan pertumbuhan yang stagnan bagi tanaman. Besarnya nilai KTK dipengaruhi oleh beberapa faktor diantaranya jumlah kandungan liat, bahan organik dan $\mathrm{pH}$ tanah (Oktavia 2014).

Kandungan $\mathrm{Ca}$ di lahan bekas tambang silika tergolong rendah, sementara kadar $\mathrm{Ca}$ di lahan bekas tambang kapur tergolong sangat tinggi. Kondisi ini dipengaruhi oleh bahan induk pada tanah tersebut. Kandungan unsur Mg, $\mathrm{K}$ dan $\mathrm{Na}$ di masing-masing lokasi penelitian tergolong sedang hingga rendah, bahkan untuk unsur $\mathrm{Na}$ di lahan bekas tambang silika berada dalam keadaan sedikit sekali dalam tanah sehingga tidak terukur. Ketersediaan unsur hara makro $(\mathrm{Ca}, \mathrm{Mg}, \mathrm{K}$ dan $\mathrm{Na}$ ) dalam jumlah yang cukup di dalam tanah dapat menyebabkan tanaman tidak tumbuh dengan normal.

Kejenuhan Basa (KB) pada lahan bekas tambang silika termasuk ke dalam kategori rendah. Kondisi ini sesuai dengan hasil penelitian Pudjiharta et al. (2007), dimana kejenuhan basa di lahan bekas tambang silika tergolong rendah karena nilai $\mathrm{pH}$ di lahan tersebut tergolong masam. Hal ini didukung oleh Guchi et al. (2015) yang menyatakan KB berhubungan linier terhadap $\mathrm{pH}$ tanah, apabila $\mathrm{pH}$ rendah maka kejenuhan basa akan rendah. Kondisi KB pada lahan bekas tambang kapur termasuk sangat tinggi, hal ini diduga oleh kandungan bahan induk kapur yang terdapat di lahan tersebut sehingga kejenuhan basa tergolong tinggi.

\section{SIMPULAN DAN SARAN}

\section{Simpulan}

Jumlah total jenis tumbuhan bawah yang ditemukan pada masing - masing lokasi penelitian di PT Holcim Indonesia Tbk adalah sebanyak 51 dari 24 famili yang tersebar pada lahan bekas tambang kapur sebanyak 31 jenis dan lahan bekas tambang silika 22 jenis. Tingkat keanekaragaman jenis tumbuhan bawah pada masing masing lokasi penelitian tergolong sedang. Jenis yang paling mendominasi lahan bekas tambang kapur dan silika adalah jenis Imperata cylindrica dan jenis Eulesine indica. Tumbuhan bawah yang berpotensi dijadikan sebagai cover crop di lahan bekas tambang kapur adalah jenis Ageratum conyzoides, Bidens pilosa, Mimosa pudica, Cyperus rotundus dan Eulesine indica sementara untuk lahan bekas tambang silika adalah jenis Panicum paludosum, Pennisetum polystachyon, Mimosa pudica, Calopogonium muconoides, Paspalum cartilagineum dan Paspalum conjugatum.

\section{Saran}

Tumbuhan bawah Imperata cylindrida dan Eulesine indica dapat dijadikan sebagai cover crop jenis lokal pada lahan bekas tambang. Diperlukan adanya penelitian lanjut dalam teknis pembudidayaan tumbuhan bawah yang berpotensi dijadikan sebagai tanaman penutup tanah di masing - masing lokasi penelitian.

\section{DAFTAR PUSTAKA}

Arafat NI. 2015. Pertumbuhan Desmodium heterophyllum (Willd.) DC. Sebagai tanaman penutup tanah di lahan bekas tambang silika [skripsi]. Bogor (ID): Institut Pertanian Bogor.

Darwo. 2003. Respon pertumbuhan Khaya anthoteca Dx. DA Acacia crassicarpa A. Cunn. Ex. Benth. Terhadap penggunaan endomikoriza, pupuk kompos dan asam humat pada lahan pasca penambangan semen [Tesis]. Bogor (ID): Institut Pertanian Bogor.

Gustiani A. 2015. Pola penyebaran jenis kapasan kuning (Thespesia lampas Dalz and Gibs) di savana bekol Taman Nasional Baluran [skripsi]. Bogor (ID): Institut Pertanian Bogor.

Hardjowigeno S. 2010. Ilmu Tanah. Jakarta (ID): Akademika Pressindo.

Hardjowigeno S. 2003. Klasifikasi Tanah dan Pedogenesis. Jakarta (ID): Akademika Pressindo.

Haridjaja O, Baskoro DPT, Setianingsih M. 2013. Perbedaan nilai kadar air kapasitas lapang berdasarkan metode alhricks, drainase bebas, dan pressure plate pada berbagai tekstur tanah dan hubungannya denngan pertumbuhan bunga matahari (Helianthus annus L.). J.Tanah Lingkungan 15 (2): 52 - 59.

Indriyanto. 2008. Ekologi Hutan. Jakarta (ID): PT Bumi Aksara 
Istomo, Kusmana C. 1997. Penuntun Ekologi Hutan. Laboratorium Ekologi Hutan. Bogor (ID): Fakultas Kehutanan, Institut Pertanian Bogor.

Kunarso A dan Azwar F. 2012. Keragaman jenis tumbuhan bawah pada berbagai tegakan hutan tanaman di Bekanat Sumatera Selatan. Jurnal Penelitian Hutan Tanaman 10(2) : 85 - 98.

Mahmud, Wardah, Toknok B. 2014. Sifat fisik tanah di bawah tegakan mangrove di Desa Tumpapa Kecamatan Balinggi Kabupaten Parigi Moutong. J. Warta Rimba 2(1): 129 - 135.

Mangurran 2004. Measuring Biological Diversity. Oxford (UK): Blackwell Science Ltd.

Oktavia D, Setiadi Y dan Hilwan I. 2014. Sifat fisika dan kimia tanah di hutan kerangan dan lahan pasca tambang timah Kabupaten Belitung Timur. Jurnal Silvikultur Tropika 05(3): 149 - 154.

Pratiwi EF. 2014. Karakteristik fisika tanah pada beberapa penggunaan lahan di tanah latosol darmaga dan podsolik jasinga [Skripsi]. Bogor (ID). Institut Pertanian Bogor.

Pudjiharta A, Widyawati, Adalina Y, Syafruddin. 2008. Kajian teknik rehabilitasi lahan alang - alang. $J$. Info Hutan 5(3): 219 - 230.

Pudjiharta A, Santoso E dan Turjaman M. 2007. Reklamasi lahan terdegradasi dengan revegetasi pada bekas tambang bahan baku semen. Jurnal Penelitian Hutan dan Konservasi Alam IV(3): 223 $-238$.

Ritonga IWS. 2015. Pengaruh konversi lahan hutan terhadap sifat fisika tanah (studi kasus : Desa Tugu Utara, Kecamatan Cisarua, Bogor) [Skripsi]. Bogor (ID) Institut Pertanian Bogor.

Sembiring S. 2008. Sifat kimia dan fisika tanah pada areal bekas tambang bauksit di pulau Bintan Riau. Jurnal Info Hutan V(2): 123 - 134.

Subandiono RE, Suryani E, Subardja djadja. 2014. Sifat - sifat tanah pada lahan potensial untuk pengembangan pertanian di Provinsi Jambi dan implikasi pengelolaannya. J. Tanah dan Iklim 36(1): $1-51$.

Umaternate GR, Abidjuju J dan Wuntu AD. 2014. Uji metode olsen dan bray dalam menganalisis kandungan fofat tersedia pada tanah sawah di Desa Konarom Barat Kecamatan Dumoga Utara. Jurnal Mipa UNSTRAT 3(1) : 6 - 11.

Wilson, Supriadi dan Guchi H. 2015. Evaluasi sifat kimia tanah pada lahan kopi di Kabupaten Mandailing Natal. Jurnal Online Agroekoteknologi 3(2): $642-648$ 